12 Mollica F, Pavone L, Nuciforo G, Sorge G. A case of cyclopia. Role of environmental factors. Clin Genet 1979;16:69-71.

13 Bongiovanni AM, Di George AM, Grumbach MM. Masculinization of the female infant with estrogenic therapy alone during gestation: four cases. J Clin Endocrinol 1959;19:1004-8.

14 Wilkins L. Masculinization of the female fetus due to the use of orally given progestins. JAMA 1960;172:1029-32.

15 Greenberg G, Inman WHW, Weatherall JAC, Adelstein AM. Hormonal pregnancy tests and congenital malformations. $\mathrm{Br}$ Med J 1975;ii:191-2.

16 Nora JJ, Nora AH. Preliminary evidence for a possible association between oral contraceptives and birth defects. Teratology 1973;7:24A.

17 Janerich DT, Piper JM, Glebatis DM. Oral contraceptives and congenital limb reduction defects. N Engl J Med 1974;291:697700.

18 Janerich DT, Dugan JM, Standfast SJ. Congenital heart disease and prenatal exposure to exogenous sex hormones. $\mathrm{Br} \mathrm{Med} \mathrm{J}$ 1977;i: $1058-60$.

19 Batts JA, Punnett HH, Valdes-Dapena M, Coles JW, Green WR. A case of cyclopia. Am J Obstet Gynecol 1972;112:657-61.
21) Hook EB, Heinonen OP, Shapiro S, Slone D. Maternal exposure to oral contraceptives and other female sex hormones: relation to birth defects in a prospectively ascertained cohort of 50,282 pregnancies. Teratology 1974:9:21-2A.

${ }^{21}$ Robinson SC. Pregnancy outcome following oral contraceptives. Am J Obstet Gynecol 1971;109:354-8.

22 Wilson JG. Embryotoxicity of drugs in man. In: Wilson JG, Fraser FC, eds. Handbook of teratology. Vol 1. London, New York: Plenum Press, 1977:324-7.

23 Andrew FD, Christensen HD, Williams TL, Thompson MG, Wall ME. Comparative teratogenicity of contraceptive steroids in mice and rats. Teratology 1973;7:11-12A.

${ }^{24}$ Lo Scalzo B, Agrusta A, Agrusta M, Crisci A, Genovese L, Marino M. Ricerche di fetoembriotossicità sull'allilestrenolo nel Mus rattus albinus. Riv Toss Sper Clin 1983;13:9-19.

Correspondence and requests for reprints to Professor V Ventruto, Servizio di Genetica Medica, Ospedale A Cardarelli, 80131 Napoli, Italy.

\title{
Tracheo-oesophageal anomalies in the Goldenhar anomalad
}

\author{
A MENDELBERG, I ARIEL, P MOGLE, AND I ARAD \\ Departments of Pediatrics, Pathology, and Radiology, Hadassah University Hospital, Mount Scopus, \\ Jerusalem, Israel.
}

SUMMARY A case of the Goldenhar anomalad is presented with a previously undescribed association with oesophageal atresia and tracheo-oesophageal fistula. This is the second instance of a tracheobronchial-oesophageal communication being found in association with the anomalad. Awareness of this combination may facilitate future diagnosis and treatment of the anomaly.

The Goldenhar anomalad is an association of facial and auricular anomalies resulting from errors in morphogenesis of the first and second branchial arches, accompanied sometimes by vertebral, ocular, and visceral malformations. ${ }^{1}$ We describe a case with previously undescribed anomalies including tracheo-oesophageal fistula, oesophageal atresia, and hypoplasia of the cerebellum.

\section{Case report}

A $2.025 \mathrm{~kg}$ female infant was delivered after 36 weeks of uneventful gestation to a 24 year old mother. The parents were unrelated Sephardic Jews and both they and their two children were normal and in good health. The Apgar scores were 6

Received for publication 30 May 1984.

Accepted for publication 11 July 1984. and 9 at 1 and 5 minutes respectively. Increasing dyspnoea and excessive salivation were soon noted and an attempt to pass an orogastric catheter was unsuccessful.

On examination the baby was noted to have an asymmetrical facies with maxillomandibular hypoplasia, bilateral preauricular skin tags, and microphthalmia with lipodermoids on both lower palpebrae (figure a). The cardiac impulse was felt over the right chest while breath sounds were heard over the left side only. The rest of the examination was considered normal. On chest $x$-ray a hyperinflated left lung with a complete rightward shift of the mediastinal structures and opacification of the right chest was seen. Extranumerary ribs and hemivertebrae of D1 to D4 were present. The visible tip of the orogastric catheter at D3 and the presence of gastric air suggested the presence of oesophageal atresia with a tracheo-oesophageal fistula. Bronchography showed a complete absence of the right bronchial tree (figure b). The baby died at 20 hours of age.

At necropsy the right lung and the right mainstem bronchus were absent. The left lung had three lobes. The upper portion of the oesophagus was separated from the lower half and ended blindly. The lower portion opened into the trachea. The cardiac chambers and valves were normal. The ductus arteriosus and the foramen ovale were patent. The pulmonary trunk divided into two branches, both supplying the 


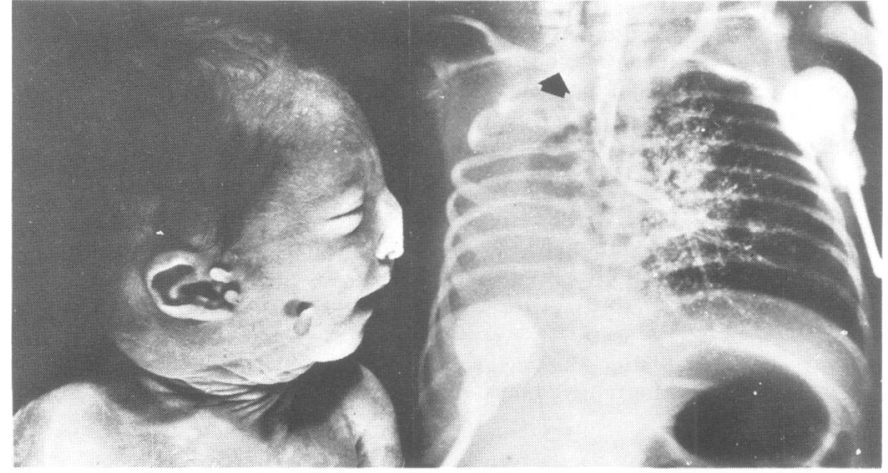

(a) (b)
FIGURE (a) Facial appearance of proband. (b) Bronchography showing absence of righ lung and mainstem bronchus. The tip of the of orogastric catheter at the blind end of the oesophagus is marked by an arrow. left lung. There were only two pulmonary veins draining the left lung. A small spleniculus was found at the hilus of the spleen. The cerebellum was markedly hypoplastic.

\section{Discussion}

Sinçe the first description of the Goldenhar anomalad in $1952,{ }^{2}$ variable combinations of facial, oral, auricular, vertebral, ocular, and cardiac malformations have been described. Other occasional abnormalities include branchial cleft remnants, laryngeal anomalies, hypoplasia or aplasia of the lung, occipital encephalocele, and renal and limb anomalies. ${ }^{1}$ The combination of oesophageal atresia and pulmonary agenesis has been reported in 14 cases, recently summarised. ${ }^{3}$ Such an association with the Goldenhar anomalad has not been previously described. Bowen and Parry, ${ }^{4}$ however, described a patient with bronchopulmonary-foregut communication and hypoplasia of the right lung but with a patent oesophagus. Thus, our report is the second instance where tracheobronchial-oesophageal com-

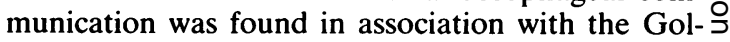
denhar anomalad. Awareness of this combination may facilitate future diagnosis and treatment of the $\frac{7}{0}$ anomaly.

\section{References}

${ }^{1}$ Smith DW. Facio-auricular-vertebral spectrum. In: Recognizable patterns of human malformation. 3rd ed. Philadelphia: Saunders, 1982; 497-500.

2 Goldenhar M. Associations malformatives de l'oeil et de l'oreille, en particulier le syndrome dermoide epibulbaire- مِ appendices auriculaires-fistula auris congenita et ses relations avec la dysostose mandibulo-faciale. J Genet Hum 1952;1:24382.

3 Brereton RJ, Rickwood AMK. Esophageal atresia with pulmonary agenesis. J Pediatr Surg 1983;18:618-20.

4 Bowen AD, Parry WH. Bronchopulmonary-foregut malformation in the Goldenhar anomalad. $A J R$ 1980;134:186-8.

Correspondence and requests for reprints to Dr Ilan Arad, NICU, Department of Pediatrics, Hadassah 3 University Hospital, Mount Scopus, Jerusalem 21940, Israel.

\section{Severe pseudoachondroplasia with parental consanguinity}

\section{D YOUNG AND J R MOORE}

Department of Child Health, Leicester Royal Infirmary, Leicester.

SUMMARY A boy who showed features of the severe form of pseudoachondroplasia, whose parents were first cousins, is reported. Published reports supporting the existence of an autosomal recessive form of this disorder are reviewed.

Received for publication 25 May 1984 Accepted for publication 11 July 1984
Pseudoachondroplasia comprises a relatively common form of short limbed dwarfism with involve- $\stackrel{0}{-}$ ment of the spine, metaphyses, and epiphyses, but $\stackrel{\mathbb{Q}}{\rightarrow}$ not the skull. Clinically different grades of severity can be recognised and provisionally four forms, $\overrightarrow{0}$ severe and mild, dominant and recessive, have been $\overrightarrow{\mathbb{D}}$ identified. ${ }^{1}$ In this report a child who showed $\frac{?}{\mathbb{D}}$ features of severe pseudoachondroplasia is de- $\varrho$ scribed. The parents were first cousins. 